\title{
Using Cesium-137 to estimate soil particle redistribution by wind in an arid region of central Iran
}

\author{
Fatemeh Gheysari a, Shamsollah Ayoubi a, *, Mohammad Reza Abdi b \\ a Department of Soil Science, College of Agriculture, Isfahan University of Technology, Isfahan, Iran \\ b Department of Physics, Faculty of Science, University of Isfahan, Isfahan, Iran
}

\section{Article Info}

Received : 28.01.2016

Accepted : 01.04.2016

\begin{abstract}
This study was conducted to estimate soil erosion and deposition rates along a transect using ${ }^{137} \mathrm{Cs}$ technique in an arid of Isfahan Province, central Iran. Sixteen sites along a northeast-southwest transect with $42 \mathrm{~km}$ length were used. Eighty soil samples collected from five depths $(0-5,5-10,10-20,20-30,30-50 \mathrm{~cm})$ were analyzed for ${ }^{137} \mathrm{Cs}$ concentration. Additional 20 soil samples were collected from the reference site for computing soil loss and deposition using ${ }^{137} \mathrm{Cs}$ measurement. The results showed that the northern part of the transect showed erosion rates ranging from12.90 to 46.86 tha${ }^{1} \mathrm{yr}^{-1}$. The major factor affecting soil erosion process in northern part of the studied transect is associated dominantly with occurrence of improper gypsum mining operations and human activities. In the southern part of the transect deposition rates changed between 3.10 - $7.44 \mathrm{t} \mathrm{ha}^{-1} \mathrm{yr}^{-1}$, presumably influenced by increasing plant cover. Significant correlations between ${ }^{137} \mathrm{Cs}$ and magnetic susceptibility, soil organic matter (SOM), total nitrogen (TN) and particle size distributions indicated that soil redistribution by wind erosion might have modified the soil properties along the studied transect. A multiple linear regression model was developed for estimating ${ }^{137} \mathrm{Cs}$ by frequency dependence $\left(\chi_{\mathrm{fd}}\right), \mathrm{TN}$, clay and sand contents which explained about $87 \%$ of the ${ }^{137} \mathrm{Cs}$ variability. This study of using ${ }^{137} \mathrm{Cs}$ to assess wind erosion is unique in the arid region of central Iran and had significant implications for further research.
\end{abstract}

Keywords: ${ }^{137} \mathrm{CS}$ inventory, oil redistribution, wind erosion.

(C) 2016 Federation of Eurasian Soil Science Societies. All rights reserved

\section{Introduction}

Wind erosion is one of the most basic processes of land degradation and environmental concerns in the arid and semi-arid regions (Hennessy et al., 1986; Okin et al., 2001). Moreover, wind erosion is identified as one of the most serious environmental and agricultural threats in many arid regions of the world (Gomes et al., 2003; Zhao et al., 2006). Soil erosion leads to desertification and air pollution. Wind erosion like water erosion leads to coarsening soil texture by the loss of fine textured materials, decreasing of soil organic matter and degeneration of vegetation (Zhang et al., 2007).

Arid and semiarid environment is the main climatic conditions in the central Iran, as well as 80 million $\mathrm{km}^{2}$ of Iran (> 50\%) is affected by wind erosion. During the last decades the area affected by wind erosion and desertification processes has increased as a result of human activity, climate change and recent drought

\footnotetext{
${ }^{*}$ Corresponding author.

Department of Soil Science, College of Agriculture, Isfahan University of Technology, Isfahan 84156-83111 Iran

Tel.: +983133913470

E-mail address: ayoubi@cc.iut.ac.ir

e-ISSN: $2147-4249$

DOI: 10.18393/ejss.2016.4.285-293
} 
(Karimzadeh, 2001). Thus, it is crucial to control wind erosion in the arid regions of Iran as the most serious environmental problem. In this regard, the information on the rate of soil erosion is needed for developing management practices and for making strategic decisions.

Since 1930s the studies on wind erosion have been conducted to make estimates of soil loss by wind erosion. Many erosion models have been used to predict soil erosion by wind (Woodruff and Siddoway, 1965; Skidmore and Powers , 1982, Shao et al., 1996; Hagen, 1991). But, most of the developed models require a large empirical components and it has not been possible to extend them beyond the area for which they were developed. In recent years, ${ }^{137} \mathrm{Cs}$ technique has been used to estimate the rates of soil erosion by wind (Yan et al., 2002; Yan and Shi, 2004; Li et al., 2005; Zhao et al., 2006). ${ }^{137} \mathrm{Cs}$ is an artificial radionuclide with a high gamma radiation and half-life of 30.2 years, which is released into the environment as a result of nuclear weapons tests primarily during the $1950-1970 .{ }^{137} \mathrm{Cs}$ fallout reaches the earth's surface mostly as a result of precipitation and is strongly and is rapidly adsorbed by fine soil colloidal particles such as clay minerals and organic matter in the topsoil. Chemical or biological removal of ${ }^{137} \mathrm{Cs}$ from soil particles is limited and it is assumed that only physical processes that result in moving soil particles such as soil erosion and tillage particle are involved in the ${ }^{137} \mathrm{Cs}$ transport (Afshar et al., 2010; Rahimi et al., 2013).

Zhang et al. (2007) used ${ }^{137} \mathrm{Cs}$ tracer in tunnel to test the erodibility of soils in Tibet. They reported that alpine meadows have the highest resistance to wind erosion and the undamaged alpine meadow soils generally sustain only weak or no wind erosion. Yan et al. (2002) by analyzing the pattern of ${ }^{137}$ Cs inventory showed that the shrub coppice dunes and semi-fixed dune fields experienced the alteration of erosion and deposition.

Although, a few studies (Afshar et al., 2010; Rahimi et al., 2013; Ayoubi et al., 2012) have been conducted in the semiarid regions of western Iran for the estimation of water erosion rate by ${ }^{137} \mathrm{Cs}$ technique, but so far no investigation has been reported in the arid region of Iran using ${ }^{137} \mathrm{CS}$ for the prediction of wind erosion till now. Therefore, as the first report, this study was performed to i) estimate soil redistribution by wind using ${ }^{137} \mathrm{Cs}$ as a tracer and (ii) explore the relationships among physicochemical and magnetic susceptibility properties with ${ }^{137} \mathrm{Cs}$ as an indicator of soil redistribution, along northeast - southwest transect across the Segzi district, east of Isfahan, central Iran.

\section{Material and Methods}

\section{Study area}

The study area is located between $32^{\circ} 34^{\prime} 8^{\prime \prime}$ to $32^{\circ} 50^{\prime} 37^{\prime \prime} \mathrm{N}$ latitudes and $51^{\circ} 58^{\prime} 43^{\prime \prime}$ to $52^{\circ} 3^{\prime} 4^{\prime \prime} \mathrm{E}$ longitude, $2120 \mathrm{~m}$ a.s.l in Segzi district, Isfahan province, central Iran (Figure 1). Mean annual precipitation is $106 \mathrm{~mm}$, mean annual potential evaporation is $2201.5 \mathrm{~mm}$, and the mean annual temperature is $15.2{ }^{\circ} \mathrm{C}$. Segzi district has a desert climate and wind speed of $60 \mathrm{~km} \mathrm{hr}^{-1}$. The area predominantly included two major geomorphic surfaces of pediments and play as according to Krinsley (1970).

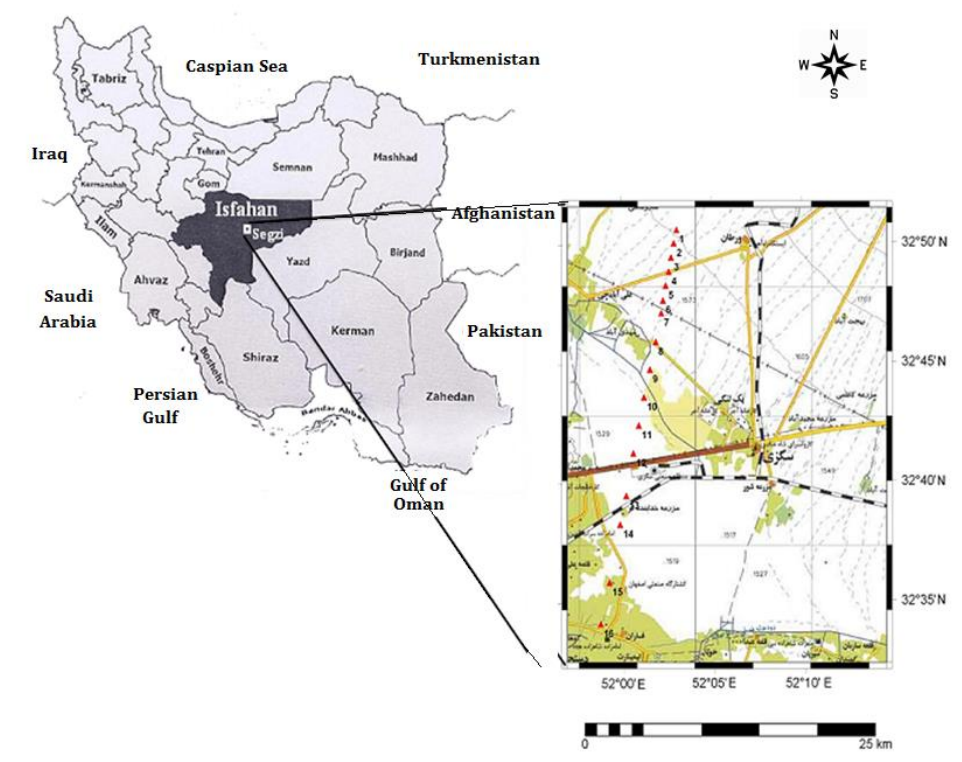

Figure 1. Location of the study site in the along northeast - southwest transect across the Segzi, east of Isfahan, central 


\section{Soil sampling}

Sixteen sites with $2.5 \mathrm{~km}$ apart in a northeast to southwest transect across the Segzi district (42 km in length) were selected (Figure 1). In each site, soil samples were taken from five depths: 0-5, 5-10, 10-20, 2030 and $30-50 \mathrm{~cm}$ at the year of 2012 (total of 80 soil samples). A reference site covered by desert varnish indicating surface stability for long period of time, was selected in nearby transect. Two cores from the reference site were drilled and 20 soil samples were collected from 0 to $50 \mathrm{~cm}$ depth with an increment of 5 $\mathrm{cm}$ to evaluate the Cs-inventory and physicochemical analysis.

\section{Laboratory analysis and ${ }^{137} \mathrm{Cs}$ measurements}

Air-dried soil samples thoroughly sieved with a 2-mm sieve. Samples each of $500 \mathrm{~g}$ were placed in Marinelli beakers and sealed for ${ }^{137} \mathrm{Cs}$ analyses. The ${ }^{137} \mathrm{Cs}$ activity was measured at Department of Physics, University of Isfahan (Iran), from the net area under the full-energy peak at $662 \mathrm{KeV}$ (ISO 11929-1, 2000), using gamma spectroscopy with a high-resolution germanium detector. Quality control of measurements was done by the reference material No: IAEA-375 from the International Atomic Energy Agency (IAEA), Analytical Quality Control Services. The count time was approximately $130 \mathrm{~min}$, with counting error at $<10 \%$ and $95 \%$ confidence level. The ${ }^{137} \mathrm{Cs}$ activities (Bq kg${ }^{-1}$ ) were converted to area activities (Bq $\mathrm{m}^{-2}$ ) (Walling et al., 2002).

Soil bulk density was determined using the core method (Blake and Hartge, 1986). Calcium carbonate equivalent (CCE) was measured by Bernard's calcimeter method (Black et al., 1965). Soil particle size distribution was obtained by the Bouyoucos hydrometer method (Gee and Bauder, 1986). Soil pH was measured in saturated paste using pH electrode (Soil Survey Division Staff, 1993) and electrical conductivity (EC) in the extract using conductivity meter (Rhoades, 1982). Soil organic matter (SOM) was determined using a wet combustion method (Nelson and Sommers, 1982) and total nitrogen (TN) by the Kjeldahl digestion method (Bremner and Mulvaney, 1982). Gravel content was measured volumetrically after sieving by a $2 \mathrm{~mm}$ sieve. $\mathrm{CaSO}_{4}$ was determined by heating at $110{ }^{\circ} \mathrm{C}$ method (Porta, 1998).

Magnetic susceptibility was measured at low $(0.46 \mathrm{kHz})$ and high frequency $(4.6 \mathrm{kHz})$ using a Bartington MS2 dual frequency sensor. The $\chi$ value is relative to the concentration of the ferrimagnetic minerals (magnetite and maghemite) in the sample and is also sensitive to the magnetic grain size (Dearing, 1999). The percentage of frequency dependence $(\chi \mathrm{fd} \%)$ was determined by the following equation:

$$
\chi_{f d}=\left(\frac{\chi_{l f}-\chi_{h f}}{\chi_{l f}}\right) \times 100
$$

where, $\chi_{\mathrm{lf}}$ and $\chi_{\mathrm{hf}}$ are magnetic susceptibility at low and high frequencies respectively.

\section{Computational methods}

Soil particle redistribution rate at any sampling site could be assessed by establishing a quantitative relationship between the rate of deposition or erosion and the changes of ${ }^{137} \mathrm{Cs}$ inventory compared with the baseline. In this paper, a simple but empirical linear model was employed to assess soil erosion rates following the approach of Ritchie and McHenry (1990) and Walling and Quine (1993):

$$
\begin{gathered}
E=\frac{C P R \times B D \times D_{i} \times 10^{4}}{T} \\
C P R=\frac{(C P I-C R I)}{C R I} \times 100
\end{gathered}
$$

where $E$ is the net wind erosion rate of the sample site ( $\left.\mathrm{t} \mathrm{ha}^{-1} \mathrm{y}^{-1}\right), C P R$ is the loss of ${ }^{137} \mathrm{Cs}(\%)$ (Eq. 3), $B D$ refers to the bulk density of sampled soil $\left(\mathrm{t} \mathrm{m}^{-3}\right), T$ is the time period between the year of maximum ${ }^{137} \mathrm{Cs}$ fallout (1963) and the sampling year (2012); in this study, $T=49$ year. The sampling increment, Di, was previously used as the plough depth for farmland (Ritchie and McHenry, 1990). But, for the uncultivated soils in the studied area, according to the depth distribution of ${ }^{137} \mathrm{Cs}$ activity (Figure 3 ), $\mathrm{D}_{\mathrm{i}}$ was considered to be $0.2 \mathrm{~m}$. In the Eq. 3, $C P R$ is ${ }^{137} \mathrm{Cs}$ percentage residual at a sampling site in the field relative to the native control area (\%), CPI is ${ }^{137} \mathrm{Cs}$ inventory $\left(\mathrm{Bq} \mathrm{m}^{-2}\right)$ in the studied site, CRI represents ${ }^{137} \mathrm{Cs}$ reference inventory $\left(\mathrm{Bq} \mathrm{m}^{-2}\right)$. 


\section{Data analysis}

Descriptive statistics including mean, minimum, maximum, coefficient of variation (CV), standard deviation (SD), and skewness were calculated using Statistical Package for the Social Sciences (SPSS), v.16. The distribution of variables was assessed using the Kolmogorov-Smirnov test (Massey, 1951). The correlations among the variables as well as of ${ }^{137} \mathrm{Cs}$ and magnetic measures with physicochemical properties were examined using the SPSS software (Swan and Sandilands, 1995). A stepwise regression procedure was employed by regressing magnetic susceptibility on the ${ }^{137} \mathrm{Cs}$ inventory and soil physico-chemical properties. Selection of the factors for inclusion in the model was based on the probability $<0.05$ (Freund and Littell, 2000).

\section{Results and Discussion}

\section{Descriptive statistics}

A summary of descriptive statistics of ${ }^{137} \mathrm{Cs}$ inventory, soil magnetic and physico-chemical parameters in all sampled soils are given in Table 1 . All parameters are normally distributed, except for $\chi_{\mathrm{fd}}$, as confirmed by the Kolmogorov-Smirnov test, and as indicated by skewness values, which varied from -1 to 1 (Table 1). The coefficient of variation (CV) of the ${ }^{137} \mathrm{Cs}$ concentration in the selected soils was $47.83 \%$. According to the classification proposed by Wilding $(1985),{ }^{137} \mathrm{Cs}$ in the study area was classified as highly variable (CV > 0.35). Magnetic susceptibility at high frequency, EC and silt also showed high variability with CV values of 109.87, 102.8 and 47.47\%, respectively. While, SOM, TN, $\mathrm{CaCO}_{3}$, clay, sand, $\chi$ lf and $\chi_{\mathrm{fd}}$ were classified as moderately variable $(0.15<\mathrm{CV}<0.35)$. Remaining variables including $\mathrm{pH}, \mathrm{BD}$ and showed low variability $(\mathrm{CV}<0.15)$ in the studied region.

Table 1. Descriptive statistics for ${ }^{137} \mathrm{Cs}$ and physico-chemical properties along the northeast - southwest transect across the Segzi, East of Isfahan, Iran

\begin{tabular}{|c|c|c|c|c|c|c|c|}
\hline Variable & Unit & Min & Max & Mean & SD & CV (\%) & Skewness \\
\hline${ }^{137} \mathrm{Cs}$ & $\mathrm{Bq} \mathrm{m}^{-2}$ & 255.00 & 1312.50 & 681.50 & 326.08 & 47.83 & 0.78 \\
\hline $\mathrm{TN}$ & $\%$ & 0.10 & 0.31 & 0.17 & 0.05 & 29.41 & 0.78 \\
\hline SOM & $\%$ & 0.10 & 0.63 & 0.40 & 0.12 & 30.00 & -0.47 \\
\hline EC & $\mathrm{dS} \mathrm{m}^{-1}$ & 1.80 & 61.29 & 48.63 & 50.00 & 102.80 & 1.10 \\
\hline $\mathrm{pH}$ & - & 7.30 & 8.51 & 7.94 & 0.36 & 4.53 & -0.02 \\
\hline $\mathrm{CaCO}_{3}$ & $\%$ & 29.40 & 69.50 & 53.71 & 9.67 & 18.00 & -0.88 \\
\hline Clay & $\%$ & 10.00 & 19.00 & 13.14 & 2.49 & 18.9 & 1.00 \\
\hline Silt & $\%$ & 12.00 & 36.30 & 36.63 & 17.39 & 47.47 & -0.04 \\
\hline Sand & $\%$ & 20.00 & 76.30 & 50.23 & 18.66 & 37.14 & -0.03 \\
\hline $\mathrm{BD}$ & $\mathrm{g} \mathrm{cm}^{-3}$ & 1.27 & 1.78 & 1.44 & 0.14 & 9.72 & 0.90 \\
\hline$\chi \mathrm{lf}$ & $10^{-8} \mathrm{~m}^{3} / \mathrm{kg}$ & 36.47 & 85.78 & 63.95 & 14.22 & 22.23 & -0.13 \\
\hline$\chi \mathrm{fd}$ & $10^{-8} \mathrm{~m}^{3} / \mathrm{kg}$ & -0.37 & 3.30 & 0.81 & 0.89 & 109.87 & 1.64 \\
\hline
\end{tabular}

Min: minimum: Max: maximum: SD: Standard deviation: CV: Coefficient of variation; 137-Cs: Radioactive cesium -137 inventory; TN: Total nitrogen; SOM: Soil organic matter; EC: Electrical conductivity; pH: Soil reaction; BD: Bulk Density; $\chi$ lf: Magnetic susceptibility at low frequency; $\chi \mathrm{fd}$ : Dependent frequency

These results show a high variably in ${ }^{137} \mathrm{Cs}$ distribution induced by wind erosion via soil redistribution along the transect. It seems that high variably in ${ }^{137} \mathrm{Cs}$ distribution was induced by soil erosion and deposition along the studied transect. Afshar et al. (2010) obtained similar CV value of 50\% for ${ }^{137} \mathrm{Cs}$ inventory in Ardal district in west of Iran. On the contrary, Ayoubi et al. (2012) reported CV value of $103.9 \%$ for ${ }^{137}$ Cs inventory in Chelgerd district in west of Iran.

\section{${ }^{137}$ Cs activity and wind erosion assessment}

${ }^{137} \mathrm{Cs}$ reference inventory refers to the amount of $137 \mathrm{Cs}$ accumulated at the study site from atmospheric ${ }^{137} \mathrm{Cs}$ fallout without any effects of wind erosion and deposition processes and human disturbance (Walling and Quine, 1993). The ${ }^{137} \mathrm{Cs}$ inventory of the two reference cores collected from the reference site had mean value of $1143.75 \mathrm{~Bq} \mathrm{~m}^{-2}$ (Figure 2). The mean value obtained in the present study is lower than those reported by Afshar et al. (2010), Ayoubi et al. (2012) and Rahimi et al. (2013) in some semiarid regions of Iran. The lower Cs-137 inventory at the studied site compared to the western Iran ascribes to lower precipitation in the arid region. Overall fall out of ${ }^{137} \mathrm{Cs}$ in a specific site is influenced significantly by the 
precipitation and rainfall (Palsson et al., 2002). In the arid selected area, annual precipitation is approx. 110 $\mathrm{mm}$ per year, whereas in the semiarid regions in western Iran precipitation exceeds $600 \mathrm{~mm} \mathrm{yr}^{-1}$.

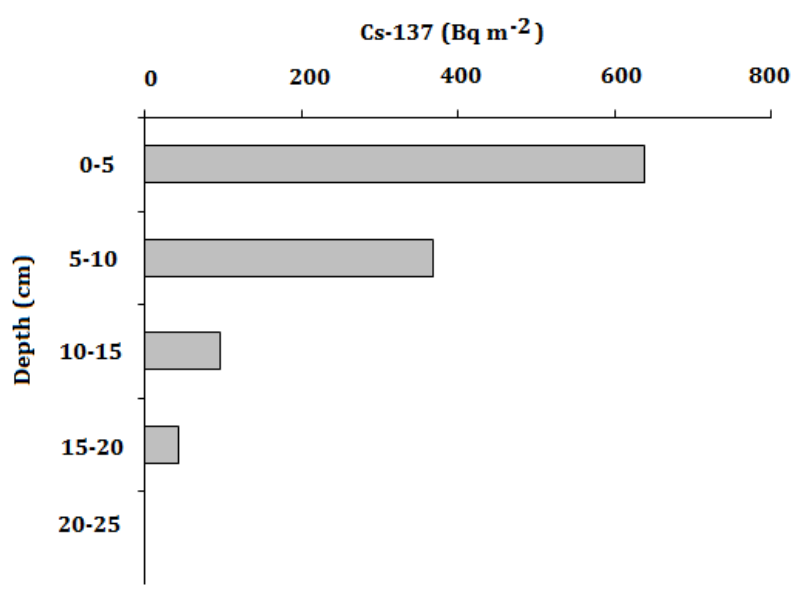

Figure 2. Vertical distribution of ${ }^{137} \mathrm{Cs}$ inventory at the reference site in the studied area

The mean values of ${ }^{137} \mathrm{Cs}$ inventory and $\%$ loss of ${ }^{137} \mathrm{Cs}$ at the studied sites as compared to the mean value of 137 Cs inventory at the reference site are given in Table 2 . The lowest and highest values of ${ }^{137}$ Cs inventory, 255 and $1312.5 \mathrm{~Bq} \mathrm{~m}^{-2}$ were observed in sites of $\mathrm{X}_{3}$ and $\mathrm{X}_{11}$, respectively. The concentration of $137 \mathrm{Cs}$ in natural and undisturbed soils decreased sharply with depth and was represented by the exponential function: Cs= ae-bx (Figure 2) (Walling and Quine, 1990; Afshar et al., 2010). While in the disturbed soils, the ${ }^{137} \mathrm{Cs}$ activity profiles exhibited deviation to varying degrees (Figure 3 ). This confirmed that the ${ }^{137} \mathrm{Cs}$ inventory at different sites have been affected by erosion or/and deposition processes and human disturbances.

Through sites $X_{1}$ to $X_{8}$, in the northern side of transect, the ${ }^{137} \mathrm{Cs}$ in the $0-10 \mathrm{~cm}$ declined compared as the reference site, indicating the dominance of soil erosion processes. The wind soil erosion rate in this part of the transect varied from 12.90 to $46.98 \mathrm{t} \mathrm{ha}^{-1} \mathrm{yr}^{-1}$ (Table 2). Ping et al (2000) assessed the average wind erosion rate in the Qinghai Tibetan Plateau using ${ }^{137} \mathrm{Cs}$ techniques to be $47.59 \mathrm{t} \mathrm{ha}^{-1} \mathrm{yr}^{-1}$. Yan and Shi (2004) calculated wind erosion rates using ${ }^{137} \mathrm{Cs}$ technique of $24.91 \mathrm{t} \mathrm{ha}^{-1} \mathrm{yr}^{-1}$ in Gonghe basin, Qinghe province, China.

Table 2. Rates of ${ }^{137} \mathrm{Cs}$ loss and the estimated corresponding wind erosion rate at the sampling sites along the northeast - southwest transect across Segzi.

\begin{tabular}{cccc}
\hline Sampling site & 137Cs inventoryn $\left(\mathrm{Bq} \mathrm{m}^{-2}\right)$ & 137Cs loss $(\%)$ & Soil erosion rate $\left.\mathrm{t} \mathrm{ha}^{-1} \mathrm{yr}^{-1}\right)$ \\
\hline X1 & 915 & -20.00 & 12.90 \\
X2 & 652.5 & -42.95 & 31.19 \\
X3 & 255 & -77.70 & 41.17 \\
X4 & 300 & -73.77 & 46.98 \\
X5 & 527.5 & -53.88 & 31.17 \\
X6 & 375 & -67.21 & 40.75 \\
X7 & 642.5 & -43.82 & 29.47 \\
X8 & 537.5 & -53.00 & 31.56 \\
X9 & 1300 & +13.65 & -7.21 \\
X10 & 1209.97 & +5.79 & -3.10 \\
X11 & 1312.5 & +14.74 & -7.64 \\
X12 & 662.5 & -42.07 & 23.30 \\
X13 & 550 & -51.91 & 32.02 \\
X14 & 652.5 & -42.95 & 23.39 \\
X15 & 787.5 & -31.15 & 17.93 \\
X16 & 357.5 & -68.74 & 37.71 \\
\hline
\end{tabular}

It seems that high rate of soil erosion by wind in this part is ascribed mainly to improper management in gypsum mining around the sites $\mathrm{X}_{1}-\mathrm{X}_{4}$ by local inhabitants. Karimzadeh (2001) also in a preliminary study in determining significant factors affecting wind erosion in east of Isfahan stated that disposal of mine tailing was the most important environmental issue of desertification in this region. The plant's absence and little green cover also accelerated detachment process of fine materials (Hupy, 2004). 
Enhancement of cesium-137 inventory was observed in the sites $X_{9}, X_{10}$ and $X_{11}$ which showed 13.65, 5.79 and $14.74 \%$ increasing compared to the reference site. The average soil deposition in these sites was 7.21, 3.1, and $7.64 \mathrm{t} \mathrm{ha}^{-1} \mathrm{yr}^{-1}$ (Table 2). A typical vertical distribution of cesium inventory for site 11 is illustrated in Fig. 3b. As it is seen in the profile, the lower layers (20-50 cm depth) showed a uniform distribution, but the upper layer showed non-normal (biased) distribution, indicating that deposition of enriched ${ }^{137}$ Cs materials. Overall, this distribution pattern is very similar to the pattern other workers have reported for the deposition sites (Yan et al., 2002). Deposition processes in these sites might be attributed to increasing plant cover which trapped the soil particles transported from other sites. Sites $\mathrm{X}_{12}$ to $\mathrm{X}_{16}$ showed a different pattern to the previously discussed sites. These sites indicated net erosion rates ranged from 17.93 to 37.71 $\mathrm{t} \mathrm{ha}^{-1} \mathrm{yr}^{-1}$. As seen (Figure 3c) in the 5-10 $\mathrm{cm}$ depth, these profiles have experienced complex deposition and erosion processes and thus they show non-normal distribution of ${ }^{137} \mathrm{Cs}$ with depth. Similar results by wind erosion were reported by Ping et al. (2000) in Qinghai-Tibet plateau, China.

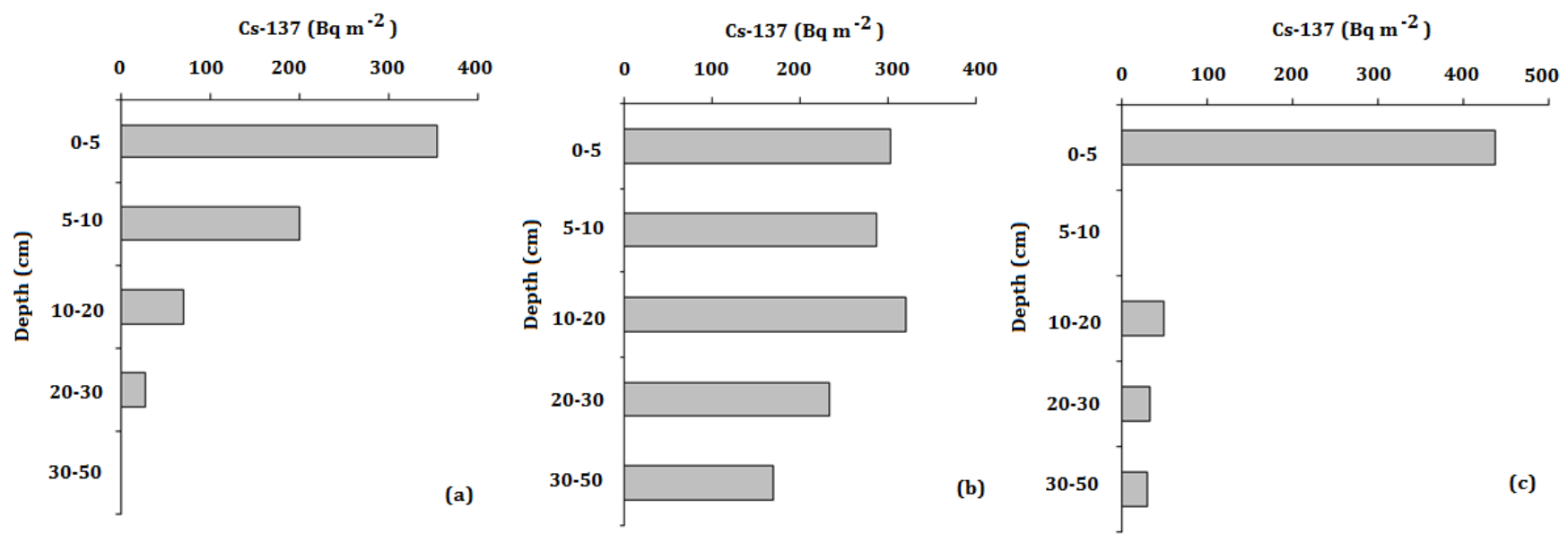

Figure 3. Vertical distribution of ${ }^{137} \mathrm{Cs}\left(\mathrm{Bq} \mathrm{m}^{-2}\right)$ at site $\mathrm{X}_{3}(\mathrm{a})$, site $\mathrm{X}_{11}(\mathrm{~b})$ and site $\mathrm{X}_{14}$

\section{Interrelations among soil properties and ${ }^{137} \mathrm{Cs}$ inventory}

The linear correlation coefficients of Cs-137 inventory with the selected soil physico-chemical and magnetic parameters in all studied soil samples are given in Table 3 . The results showed significant positive correlations of clay content $\left(r=0.63^{* *}\right)$, silt content $\left(r=0.50^{*}\right)$, SOM $\left(r=0.63^{* *}\right)$, TN $\left(0.83^{* *}\right)$ and EC $(r=$ $0.62^{* *}$ ) with ${ }^{137} \mathrm{Cs}$ inventory. Positive correlation of soil fine particles and organic matter with ${ }^{137} \mathrm{Cs}$ indicated that ${ }^{137} \mathrm{Cs}$ has been adsorbed and stabilized by clay and organic colloids. Staunton and Roubaud (1997) found a high covalent interaction between $\mathrm{Cs}$ and the clay surface. There were significant negative correlations of sand content $\left(\mathrm{r}=-0.55^{*}\right), \mathrm{pH}\left(\mathrm{r}=-0.70^{* *}\right)$, and $\mathrm{CaCO}_{3}\left(\mathrm{r}=-0.53^{*}\right)$ with ${ }^{137} \mathrm{Cs}$ inventory (Table 3$)$. These results are agreement with the findings of Afshar et al. (2010) and Rahimi et al. (2013) in western Iran.

Table 3. Correlation coefficients among soil physico-chemical properties and radioactive ${ }^{137} \mathrm{Cs}$ at the site studied $(\mathrm{n}=80)$.

\begin{tabular}{|c|c|c|c|c|c|c|c|c|c|c|c|c|}
\hline & ${ }^{137} \mathrm{Cs}$ & TN & SOM & $\mathrm{EC}$ & $\mathrm{pH}$ & Clay & Sand & Silt & $\mathrm{CaCO}_{3}$ & $\mathrm{CaSO}_{4}$ & Gravel & $\mathrm{BD}$ \\
\hline$! 37 \mathrm{Cs}$ & 1 & & & & & & & & & & & \\
\hline TN & $0.83^{* *}$ & 1 & & & & & & & & & & \\
\hline SOM & $0.63^{* *}$ & $0.55^{*}$ & 1 & & & & & & & & & \\
\hline EC & $0.62^{* *}$ & $-0.63^{* *}$ & $0.54 *$ & 1 & & & & & & & & \\
\hline $\mathrm{pH}$ & $-0.7^{* *}$ & $-0.52^{*}$ & $-0.58^{*}$ & $-0.76^{* *}$ & 1 & & & & & & & \\
\hline Clay & $0.63^{* *}$ & $0.53^{*}$ & $0.68^{* *}$ & $0.77^{* *}$ & $-0.68^{* *}$ & 1 & & & & & & \\
\hline Sand & $-0.55^{*}$ & -0.14 & $-0.57^{*}$ & $-0.55^{*}$ & $0.54^{*}$ & $-0.55^{*}$ & 1 & & & & & \\
\hline Silt & $0.5^{*}$ & 0.08 & $0.52^{*}$ & $0.68^{* *}$ & -0.48 & 0.44 & $-0.99 * *$ & 1 & & & & \\
\hline $\mathrm{CaCO}_{3}$ & $-0.53^{*}$ & -0.31 & -0.26 & $-0.59^{*}$ & $-0.62^{*}$ & $-0.63^{* *}$ & 0.47 & -0.42 & 1 & & & \\
\hline $\mathrm{CaSO}_{4}$ & -0.1 & -0.06 & -0.13 & 0.16 & -0.07 & 0.23 & 0.08 & -0.13 & -0.13 & 1 & & \\
\hline Gravel & -0.27 & 0.07 & -0.47 & $-0.6^{*}$ & 0.44 & -0.36 & $0.73^{* *}$ & $-0.73^{* *}$ & 0.45 & -0.15 & 1 & \\
\hline BD & 0.029 & -0.29 & -0.29 & 0.45 & 0.2 & $-0.5^{*}$ & $0.53^{*}$ & $-0.49 *$ & $0.58^{*}$ & -0.21 & $0.74^{* *}$ & 1 \\
\hline
\end{tabular}

*Significant at $95 \%,{ }^{* *}$ significant at $99 \%$ probability level

${ }^{137} \mathrm{Cs}$ : Radioactive cesium-137; TN: total nitrogen; SOM: Soil organic matter; EC: Electrical conductivity; pH: Soil reaction BD: Bulk density. 
These high statistical correlations between soil properties and ${ }^{137} \mathrm{Cs}$ inventory indicated that soil redistribution by wind likely control the variability of the selected soil properties along the studied transect. In other words, detachment and accumulation of some soil elements such as SOM, soil nutrients, and magnetic minerals and Cs-inventory associated with fine particles are regulated simultaneously along the transect.

The results of correlation analysis between ${ }^{137} \mathrm{Cs}$ inventory and magnetic parameters showed that $\chi$ lf had positive significant correlation with ${ }^{137} \mathrm{Cs}\left(\mathrm{r}=0.64^{* *}\right)$ (Figure $\left.4 \mathrm{a}\right)$; and also $\chi \mathrm{fd}$ had significant positive relationship with cesium-137 ( $\left.\mathrm{r}=0.48^{*}\right)$ in the $0-15 \mathrm{~cm}$ depth (Figure 4b). Rahimi et al (2013) reported positive correlation of magnetic susceptibility with ${ }^{137} \mathrm{Cs}$ inventory. It is presumably attributed to that factors affecting variability of ${ }^{137} \mathrm{Cs}$ probably (i.e. soil redistribution by wind) controlled the variability of magnetic particles associated with fine soil particles.
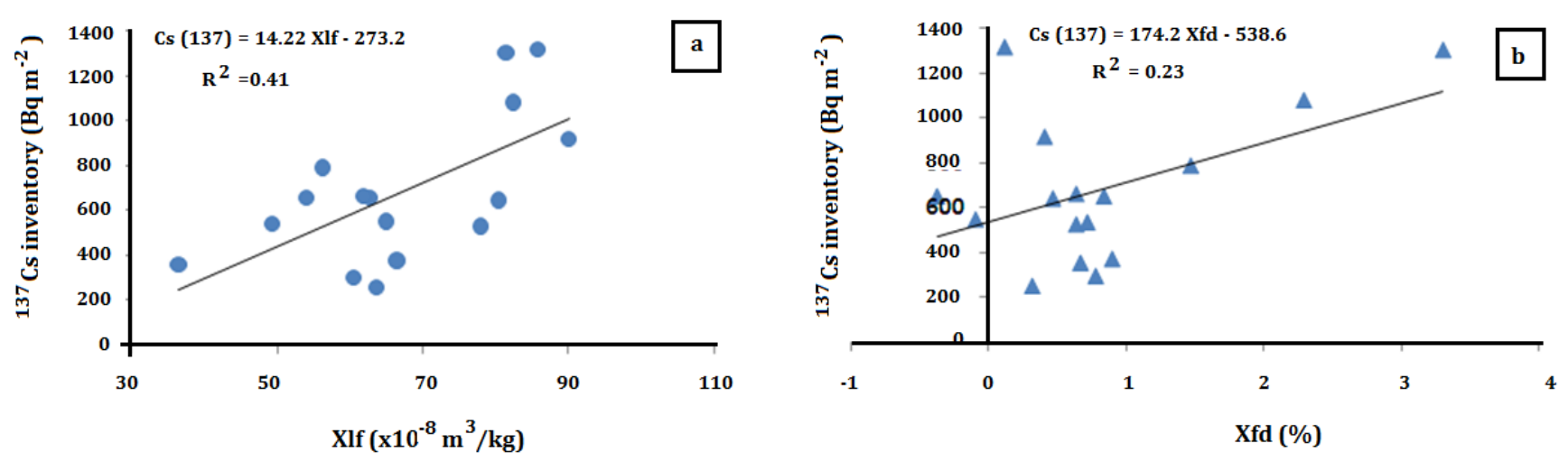

Figure 4. Linear relationships of total ${ }^{137} \mathrm{Cs}$ inventory in the studied sites with magnetic susceptibility (a) and magnetic dependency (b) and $\chi \mathrm{fd}$ : Dependent frequency in the 0-50 $\mathrm{cm}$ soil depth.

Also, a non-linear relationship was established to develop more powerful model between ${ }^{137} \mathrm{Cs}$ and magnetic susceptibility. In this regard, the following non-linear equation was developed between ${ }^{137} \mathrm{Cs}$ and $\chi_{\text {If }}$ could explain $50 \%$ of total variability of ${ }^{137} \mathrm{Cs}$ in the samples along the transect.

$$
137 \mathrm{CS}=7.5+3.87\left(\chi_{\mathrm{lf}}\right)+8.04\left(\chi_{\mathrm{lf}}\right)^{2} \quad \mathrm{R}^{2}=0.50, \mathrm{p}<0.05
$$

These results imply that soil redistribution (erosion and deposition) could likely explain the variations in magnetic susceptibly and therefore, magnetic variations have potential to be used as a proxy for soil erosion monitoring with the aim of reducing the number of ${ }^{137} \mathrm{Cs}$ analyses in the given study area affected by wind erosion processes. Mokhtari Karchegani et al. (2011) studied the efficacy magnetic measurements for assess soil redistribution in hilly regions of western Iran by water erosion. They reported that these measures could provide valuable information for soil redistribution in combined to other soil properties. Similar findings were obtained by Ayoubi et al. (2012) and Rahimi et al. (2013) in western Iran.

Moreover, a multiple linear regression (MLR) model was developed between ${ }^{137} \mathrm{Cs}$ and studied soil properties, and can be represented by the following equation.

${ }^{137} \mathrm{Cs}=346.43+209.68\left(\mathrm{TN} \times\right.$ Clay) $+105.79 \chi \mathrm{fd}-0.41$ (Sand $\times$ Clay) $\quad \mathrm{R}^{2}=0.87, \mathrm{p}<0.01$

As the equation showed, TN, clay content, $\chi \mathrm{fd}$ and sand content included in the MLR had significant effect and their combined effect could explain $87 \%$ of the total variability in the ${ }^{137}$ Cs inventory along the transect. As measurement of ${ }^{137} \mathrm{Cs}$ has been identified as one of the most reliable techniques for evaluating soil redistribution, and measurement of ${ }^{137} \mathrm{Cs}$ is so time and cost consuming, therefore the above equation could provide valuable information about CS inventory using easily available soil data at the studied site. Afshar et al. (2010) reported that among the soil properties, total nitrogen, available phosphorus, and potassium explained $41 \%$ of the total variability in the ${ }^{137} \mathrm{Cs}$ inventory in western Iran.

\section{Conclusion}

The wind erosion and deposition rate was estimated along a northeast - southwest transect across the Segzi region in central Iran using the ${ }^{137} \mathrm{Cs}$ technique. The relationships between ${ }^{137} \mathrm{Cs}$ and selected soil physical and chemical properties were also examined. The ${ }^{137} \mathrm{Cs}$ inventory of sampling site ranged from 255 to 1312.5 
$\mathrm{Bq} \mathrm{m}^{-2}$ and wind erosion rate ranged from 3.10 to $46.98 \mathrm{t} \mathrm{ha}^{-1} \mathrm{yr}^{-1}$. In almost all of the sites studied (13 from 16 sites), soil erosion has occurred; and at the depositions sites the deposition rates varied from 3.1 to $7.64 \mathrm{t}$ $\mathrm{ha}^{-1} . \mathrm{yr}^{-1}$. Soil erosion sites were mainly associated with gypsum mining operations and the deposition sites were mainly due to increasing plant cover.

The correlation analysis showed significant positive correlations between clay content, silt content, SOM, TN, EC, $\chi \mathrm{lf}$, and $\chi \mathrm{df}$ and ${ }^{137} \mathrm{Cs}$ inventory. Multiple linear regression analysis revealed that a combination of magnetic susceptibility and some easily measurable soil properties (e.g. total nitrogen, clay, sand) could explaining about $87 \%$ of total variability of ${ }^{137} \mathrm{Cs}$, and hence these variables could be used in the future research to reduce cesium measurement to assess redistribution by wind erosion in the studied region. Overall, the results of the present study for the first time in the country show that ${ }^{137} \mathrm{Cs}$ can be used for estimating wind erosion; and this has significant implications for future research in this important area in the arid region of Iran.

\section{References}

Afshar, F.A., Ayoubi, S., Jalalian, A., 2010. Soil redistribution rate and its relationship with soil organic carbon and total nitrogen using 137-Cs technique in a cultivated complex hilislope in western Iran. Journal of Environmental Radioactivity 101(8): 606-614.

Ayoubi, S., Ahmadi, M., Abdi, M.R., Afshar, F.A., 2012. Relationships of ${ }^{137}$ Cs inventory with magnetic measures of calcareous soils of hilly region in Iran. Journal of Environmental Radioactivity 112, 45-51.

Black, C.A., Evans, D.D., White, J.L., Ensminger, L.E., Clark, F.E., 1965. Methods of Soil Analysis. Part 2. Chemical and Microbiological Properties. Agronomy Monograph, Vol. 9. ASA-SSSA, Madison, WI, USA.

Blake, G.R., Hartge, K.H., 1986. Bulk density. In: Methods of Soil Analysis. Part 1. Physical and Mineralogical Methods. Klute, A. (Ed.), Agronomy Monograph, Vol. 9. ASA-SSSA, Madison, WI, USA. pp. 363-375.

Bremner, J.M., Mulvaney, C.S., 1982. Total nitrogen. In: Methods of Soil Analysis. Part 2. Chemical and Microbiological Properties. Page, A.L. (Ed.). Agronomy Monograph, Vol. 9. ASA-SSSA, Madison, WI, USA.

Dearing, J.A., 1999. Environmental magnetic susceptibility, using the Bartington MS2 System. Chi Publishers, Kenilworth, UK. 54 pp.

Freund, R.J., Littell, R.C., 2000. SAS System for Regression. SAS Inst, Cary, NC.

Gee, G.W., Bauder, J.W., 1986. Particle-size analysis. In: Methods of Soil Analysis. Part 1. Physical and Mineralogical Methods. Klute, A. (Ed.), Agronomy Monograph, Vol. 9. ASA-SSSA, Madison, WI, USA. pp. pp. 383-409.

Gomes, L., Arrúe, J.L., López, M.V., Sterk, G., Richard, D., Gracia, R., Sabre, J.M., Gaudichet, A., Frangi, J.P., 2003. Wind erosion in a semiarid area of Spain: the WELSONS project. Catena 52(3-4): 235 - 256.

Hagen, L.J., 1991. A wind erosion prediction system to meet the user need. Journal of Soil and Water Conservation 46(2): 106-111.

Hennessy, J.T., Kies, B., Gibbens, R.P., Tromble, J.M., 1986. Soil sorting by forty-five years of wind erosion on a southern New Mexico range. Soil Science Society America Journal 50(2): 391 - 394.

Hupy, J.P., 2004. Influence of vegetation cover and crust type on wind-blown sediment in a semi-arid climate. Journal of Arid Environment 58(2): 167-179.

Karimzadeh, H.R., 2001. Determination wind erosion deposits in waster Isfahan, central Iran. PhD dissertation. Isfahan University of Technology, Isfahan Iran.

Krinsley, D., 1970. A geomorphological and paleoclimatological study of the playas of Iran. Geological Survey (U.S), Air Force Cambridge Research Laboratories (U.S). Geological Survey, U.S. Dept. of the Interior, USA. 486p.

Li, M., Li, Z., Liu, P., Yao, W., 2005. Using Cesium-137 technique to study the characteristics of different aspect of soil erosion in the wind-water erosion crisscross region on Loess Plateau of China. Applied Radiation and Isoopes 62(1): 109-113.

Massey Jr., F.J., 1951. The Kolmogorov-Smirnov test of goodness of fit. Journal of the American Statistical Association 46: 68-78.

Mokhtari Karchegani, P., Ayoubi, S., Lu, S.G., Honarju, S., 2011. Use of magnetic measurements to assess soil redistribution following deforestation in hilly region. Journal of Applied Geophysics 75(2): 227-236.

Nelson, D.W., Sommers, L.E., 1982. Total carbon, organic carbon, and organic matter. In: Bartels, J.M., Bigham, J.M. (Eds.), Methods of Soil Analysis. Part 3: Chemical Methods. American Society of Agronomy, Madison WI., USA, pp. 961-1010.

Okin, G.S., Murray, B., Schlesinger, W.H., 2001. Degradation of sandy arid shrub-land environments: observations, process modeling, and management implications. Journal of Arid Environments 47(2): 123 - 144.

Palsson, S.E., Arnalds, O., Sigurgeirsson, M.A., Guonason, J., Howard, B.J., S.M. Wrighr, S.M., Palsdottir, P., 2002. Cs-137 fallout inventories in Iceland - estimating deposition from precipitation data. Radioprotection 37 (C1): C1-1223C1-1228. 
Yan, P., Shi, P., Gao, S., Chen, L., Zhang, X., Bai, L., 2002. ${ }^{137}$ Cs dating of lacustrine sediments and human impacts on Dalian Lake, Qinghai Province, China. Catena 47(2): 91-99.

Ping,Y., Zhibao, D., Guangrong, D., Xinbao, Z., Yiyun, Z., 2000. Preliminary results of using ${ }^{137}$ Cs to study wind erosion in the Qinghai-Tibet Plateau. Journal of Arid Environment 47 (4): 443-452.

Porta, J., 1998. Methodologies for the analysis and characterization of gypsum in soils: A review. Geoderma 87(1-2): 3146.

Rahimi, M.R., Ayoubi, S., Abdi, M.R., 2013. Magnetic susceptibility and Cs-137 inventory variability as influenced by land use change and slope positions in a hilly, semiarid region of west-central Iran. Journal of Applied Geophysics 89: 68-75.

Rhoades, J.D., 1982. Cation exchange capacity. In: Page, A.L., Miller, R.H., Keeney, D.R. (Eds.), Methods of Soil Analysis. Part 2. Chemical and Microbiological Properties. Agronomy Monograph, 9. ASA and SSSA, Madison, WI.

Ritchie, J.C., McHenry, J.R., 1990. Application of radioactive fallout Cs-137 for measuring soil erosion and sediment accumulation rates and patterns, Journal of Environmental Quality 19(2): 215-233.

Shao, Y., Raupach, M.R., Leys, J.F., 1996. A model for predicting Aeolian sand drift and dust entrainment on scales from paddock to region. Australian Journal of Soil Research 34(3): 309-342.

Skidmore, E.L., Powers, D.H., 1982. Dry soil-aggregate stability: energy-based index. Soil Science Society of America Journal 46(6): 1274-1279.

Soil Survey Division Staff, 1993. Soil Survey Manual. United States Department of Agriculture. Soil Conservation Service. Agriculture Handbook No. 18, USA.

Staunton, S., Roubaud, M., 1997. Adsorption of 137Cs on montmorillonite and illite: effect of charge compensating cation, ionic strength, concentration of Cs, K and fulvic acid. Clay and Clay Minerals 45(2): 251-260.

Swan, A.R.H., Sandilands, M., 1995. Introduction to Geological Data Analysis. Blackwell Science, USA. 446p.

Walling, D.E., Quine, T.A., 1990. Calibration of caesium-137 measurement to provide quantitative erosion rate data. Land Degradation and Development 2(3): 161-175.

Walling, D.E., Quine, T.A., 1993. Use of Cs-137 as a tracer of erosion and sedimentation. Hand book of the application of Cs-137 techniques. UK Overseas Development Administration, Department of Geograpy, University of Exeter. Exeter, UK. 195p.

Walling, D.E., He, Q., Appleby. P.G., 2002. Conversion models for use in soil-erosion, soil redistribution and sedimentation investigations. In: Handbook for the Assessment of Soil Erosion and Sedimentation Using Environmental Radionuclides. Zapata, F. (Ed.). Kluwer Academic Publishers. New York, USA. pp.111-164.

Wilding, L.P., 1985. Spatial variability: its documentation, accommodation, and implication to soil surveys. In: Soil Spatial Variability. Nielsen, D.R., Bouma, J., (Eds.). Pudoc, Wageningen, The Netherlands. pp. 166-194.

Woodruff, N.P., Siddoway, F.H., 1965. A wind erosion equation. Soil Science Society of America Journal 29(5): 602-608.

Yan, P., Shi, P., Gao, S., Chen, L., Zhang, X., Bai, L., $2002 .{ }^{137}$ Cs dating of lacustrine sediments and human impacts on Dalian Lake, Qinghai Province, China. Catena 47(2): 91-99.

Yan, P., Shi, P., 2004. Using the 137Cs technique to estimate wind erosion in Gonghe basin, Qinghe province, China. Soil Science 169(4): 295-305.

Zhang, C.L., Zou, X.Y., Yang, P., Dong, Y.X., Li, S., Wei, X.H., Yang, S., Pan, X.H., 2007. Wind tunnel test and 137Cs tracing study on wind erosion of several soils in Tibet. Soil and Tillage Research 94(2): 269-282.

Zhao, L.H., Yi., X.Y., Zhou, R.L., Zhao, X.Y., Zhang, T.H., Drake, S., 2006. Wind erosion and sand accumulation effects on soil properties in Horqin Sandy Farmland, Inner Mongolia. Catena 65(1): 71- 79. 